\title{
Paddy-Cum-Fish Cultivation and the Challenges Face by the Farmers of Manipur, India
}

\author{
J.W. Haobijam ${ }^{1 *}$, Marak R. Balkho ${ }^{2}$ and T.K. Mandal $^{3}$ \\ ${ }^{1}$ Department of Agricultural Extension Education, P.S.B, Visva-Bharati, Sriniketan \\ (West Bengal), India \\ ${ }^{2}$ M4agriNEI Project, College of Home Science, Central Agricultural University, Sangsanggre, \\ Tura, (Meghalaya), India \\ ${ }^{3}$ Department of Agriculture Extension Education, B.C.K.V. Mohanpur, \\ Nadia, (West Bengal), India
}

A B S T R A C T

\begin{tabular}{|c|}
\hline Keywords \\
\hline $\begin{array}{l}\text { Constraints, } \\
\text { Correlation, } \\
\text { Income, Net } \\
\text { Income, Paddy- } \\
\text { cum-Fish } \\
\text { cultivation, } \\
\text { Regression }\end{array}$ \\
\hline Article Info \\
\hline $\begin{array}{l}\text { Accepted: } \\
\text { 10 January } 2018 \\
\text { Available Online: } \\
10 \text { February } 2018\end{array}$ \\
\hline
\end{tabular}

The study was carried out with an objective to study various socio-economic, sociopersonal, socio-psychological and communication variables associated with paddy-cumfish cultivation and the constraints perceived by the farmers in the low lying paddy fields of Kakching block in Thoubal district of Manipur. Purposive along with simple random sampling techniques were adopted for the study. Net Income and Income being the dependent variables of the study to explore the factors associated with the paddy-cum- fish farmers and seventeen causal variables were considered as the independent variables to establish the relation between the dependent one. In the present study, data were generated through a sample survey of farmers by personal interview method using pretested wellstructured interview schedule and were processed into frequency, percentage, mean, standard deviation, coefficient of variation, correlation analysis, regression analysis, constraints etc. to draw conclusion the of the study. Random sampling was adopted for the selection of the respondents. Correlation analysis of the two dependent variables Net income and Income of the study revealed that out of the 17 variables, 12 and 13 independent variables were found to be significant respectively. The result of regression analysis on Net Income and Income revealed that out of 17 variables, 5 and 3 independent variables were found to be significant respectively. Constraints analysis revealed that nonavailability of insurance when the crop failed, lack of knowledge of paddy-cum-fish practices and the irregular visit of extension worker/scientist were top in their respective 3 main relative constraints.

\section{Introduction}

The Paddy-cum-fish cultivation can be practiced where paddy fields remain waterlogged for about 3 to 8 month throughout the year (Pullin et al., 1989).
Farmers' income can be increased by providing more emphasis on low-cost technology and appropriate management practices of more effective extension to the poor people and securing their right of access of land control of resources, rather than 
technical research (Edwards, 2002). Okoye (2004) reported that fundamental role in sustaining the livelihood of the rural poor in Asia is playing by the living aquatic resources. Rice-fish farming is an ancient practice in Asia (Rabbani et al., 2004; Tasnoova et al., 2008). Especially in the rain-fed agriculture system practicing subsistence farmers, integration of fish into the rice farming provides invaluable protein to them. More than one half of the animal protein available in many Asian countries is from fish. A unique agro-landscape in many countries across the world, particularly in Asian countries are created by the rice-fish system of cultivation. Such as China, Thailand, Philippines, India, Bangladesh and Indonesia ( $\mathrm{Lu}$ and $\mathrm{Li}, 2006$ ). (IDRC, 1998) reported that not only protein is available from the rice-fish culture but it also increases the actual rice yield (up to $10 \%$ in some cases) which provided extra income for the farmers. Putting into practice is relatively inexpensive and low-risk. (Saikia and Das, 2008) reported that rice-fish culture under either capture systems or culture systems in low-cost, sustainable practice. By using available local resources, traditional rice-fish culture can be turned into a low input selfsupporting system if the appropriate locationspecific refinement of packages of practices is achieved. (Ahmed and Luong-Van, 2009) reported integrated production of rice-fish culture can optimize resource use via the complementary utilization of land and irrigation water. In the rural areas of less developed countries in the tropics. It has the benefit of supplying rice as a source of carbohydrates and fish as a source of highquality protein (Frei and Becker, 2005). Reduction of lower costs of the farmer's economic load and increases in their additional income from the sale of fish are obtained at the farm level as rice-fish integration reduces the use of fertilizers, pesticides and herbicides in the fields (Noorhosseini, 2010; Noorhosseini and
Radjabi, 2010; Ahmed and Garnett, 2011). Integrated rice-fish farming also provides higher rice yields and fetches a higher gross margin than a sole rice cropping system (Das et al., 2002). Various new modern farming techniques of the rice-fish system are still lacking in the most practical area of rural sectors of the world and need to be spread as soon as possible. Integrated rice-fish farming is ecologically sound has been suggested by many reports as fish improves soil fertility by increasing the availability of nitrogen and phosphorus (Rahman et al., 2005; Ahmed et al., 2011; Ahmed and Garnett, 2011). Practicing of fish in the paddy field is an ancient traditional farming practice found in numerous rice growing area of the world and as well as in the northeastern states of India. But due to the higher uses of organic fertilizer in the recent period in the paddy field survival and practice of fish in the paddy filed become almost shattered. In a populous country like India, where the per capita availability of land and water resources is going down day by day, the need of the hour is a vertical growth in food grain production without endangering ecological assets. Therefore, integrated farming system along with fish can provide both food security and generate rural income to farmers and livelihood security to the rural workforce on an economically sustainable basis.

\section{Materials and Methods}

This study was conducted in four practiced villages viz. Wabagai, Hiyanglam, Laphupat, Khoidum from the Thoubal District in Kakching block of Manipur. Simple random sampling techniques were adopted in selecting 120 farmers. The district, block, and villages were purposively selected for the study. It may be termed as multistage random sampling procedure. Net Income and Income of the farmers practicing paddy-cum-fish cultivation were taken up as the dependent variables. In 
the context of the present study Net Income was defined as the income from an investment after deducting all expenditures from the gross income generated by the investment. Similarly, income was defined as the gross annual earnings from the mean agricultural products as well as by-products. The 17 selected independent variables were group on the basis of socio-economic (age, caste, house type, family type, material possession, family member, education, occupation), agroeconomic (operation landholding, farm power, cost of input), socio-psychological (scientific orientation, and risk orientation) and extension-communication (social participation, mass media exposure, personal cosmopolite, personal localite) characteristic. The data were collected by personal interview with the help of pre-tested interview schedule. Problems faced by farmers in adopting paddycum-fish cultivation were divided into 3 main relative constraints and the farmers were asked to rank them. Statistical tools such as frequency, percentage, mean, standard deviation, coefficient of variation, correlation and regression analysis were used to draw the logical conclusion of the study.

\section{Results and Discussion}

Table 1 presented the distribution of the 17 independent variables in terms of their mean, standard deviation, coefficient of variation and the ranks of their consistency for the paddycum-fish farmers. The independent variables exhibited highly consistent behaviour. The variables as ranked according of their consistency were scientific orientation $(0.09 \%)$, caste $(0.14 \%)$, age $(0.15 \%)$, risk orientation $(0.16 \%)$, family member $(0.19 \%)$, personal localite $(0.21 \%)$, personal cosmopolite $(0.23 \%)$, mass media exposure $(0.25 \%)$, material possession $(0.27 \%)$, house type $(0.28 \%)$, family type $(0.35 \%)$, occupation $(0.41 \%)$, operational land holding $(0.43 \%)$, social participation $(0.45 \%)$, Cost on inputs
$(0.45 \%)$, education $(0.47 \%)$, farm power $(0.59 \%)$ respectively. Table 2 highlights the correlation between 17 independent variables and the dependent variables. Correlation analysis between Net Income and other causal variables reported positively significant correlation in six socio-economic variables (caste, family type, material possession, family member, education, occupation), three agro-economic variables (operation landholding, farm power, cost of input), one socio-psychological variable (risk orientation) and one extension-communication variable (mass media exposure). Similarly 12 causal variables, 7 from socio-economic variable (caste, house type, family type, material possession, family member, education, occupation), 3 from agro-economic variable (operation landholding, farm power, cost of input), 1 from socio-psychological variable (risk orientation) and 2 from extensioncommunication variable (social participation, mass media exposure) showed positively significant correlation with Income. Family members had a negatively significant correlation with Net Income and Income respectively. It indicates that with the increase in the family member, there is higher expenditure and little surplus from the production as compared with the lower family member.

From table 3 it is clear that education, operation landholding, farm power, social participation, cost of input had a substantial effect on net income of farmers practicing paddy-cum-fish cultivation. From the table, a unit change in farm power had contributed to a proportion 0.273 unit change to the level of net income of the paddy-cum-fish cultivation farmers. Similarly, a unit change in education, operation landholding, social participation and cost of input will contribute a change in the level of net income of the paddy-cum-fish cultivation farmers by $0.158,0.238,0.273$, 0.179 and 0.237 units respectively. 
Table.1 Descriptive distribution of the variables with reference to respondent profile $(\mathrm{N}=120)$

\begin{tabular}{|c|c|c|c|c|c|}
\hline S. & Variables & \multicolumn{2}{|c|}{ Range } & Mean & Standard \\
\cline { 2 - 4 } No. & Min. & Max & & Deviation \\
\hline $\mathbf{1}$ & Age $\left(\mathrm{X}_{1}\right)$ & 34 & 64 & 47.43 & 7.06 \\
\hline $\mathbf{2}$ & Caste $\left(\mathrm{X}_{2}\right)$ & 3 & 4 & 3.58 & 0.50 \\
\hline $\mathbf{3}$ & Family Type $\left(\mathrm{X}_{3}\right)$ & 1 & 2 & 1.4 & 0.49 \\
\hline $\mathbf{4}$ & Family Member $\left(\mathrm{X}_{4}\right)$ & 1 & 2 & 1.85 & 0.36 \\
\hline $\mathbf{5}$ & Education $\left(\mathrm{X}_{5}\right)$ & 1 & 8 & 4.21 & 1.98 \\
\hline $\mathbf{6}$ & Occupation $\left(\mathrm{X}_{6}\right)$ & 1 & 7 & 4.18 & 1.70 \\
\hline $\mathbf{7}$ & Operation Landholding $\left(\mathrm{X}_{7}\right)$ & 1 & 3 & 1.78 & 0.77 \\
\hline $\mathbf{8}$ & House Type $\left(\mathrm{X}_{8}\right)$ & 1 & 3 & 2.00 & 0.55 \\
\hline $\mathbf{9}$ & Farm Power $\left(\mathrm{X}_{9}\right)$ & 0 & 3 & 1.38 & 0.81 \\
\hline $\mathbf{1 0}$ & Material Possession $\left(\mathrm{X}_{10}\right)$ & 3 & 9 & 6.37 & 1.71 \\
\hline $\mathbf{1 1}$ & Social Participation $\left(\mathrm{X}_{11}\right)$ & 0 & 3 & 1.73 & 0.78 \\
\hline $\mathbf{1 2}$ & Mass Media Exposure $\left(\mathrm{X}_{12}\right)$ & 4 & 11 & 6.83 & 1.69 \\
\hline $\mathbf{1 3}$ & Personal Cosmopolite $\left(\mathrm{X}_{13}\right)$ & 4 & 9 & 6.60 & 1.50 \\
\hline $\mathbf{1 4}$ & Personal Localite $\left(\mathrm{X}_{14}\right)$ & 3 & 10 & 7.72 & 1.63 \\
\hline $\mathbf{1 5}$ & Cost of Input $\left(\mathrm{X}_{15}\right)$ & 14500 & 118200 & 56707.78 & 25563.22 \\
\hline $\mathbf{1 6}$ & Scientific Orientation $\left(\mathrm{X}_{16}\right)$ & 15 & 22 & 18.15 & 1.72 \\
\hline $\mathbf{1 7}$ & Risk Orientation $\left(\mathrm{X}_{17}\right)$ & 7 & 20 & 18.15 & 2.85 \\
\hline $\mathbf{1 8}$ & Net Income $\left(\mathrm{Y}_{1}\right)$ & 28800 & 185100 & 80857.23 & 37592.45 \\
\hline $\mathbf{1 9}$ & Income $\left(\mathrm{Y}_{2}\right)$ & 34000 & 280000 & 124829.6 & 61945.77 \\
\hline
\end{tabular}

Table.2 Coefficient of correlation of net income and income with 17 causal variables

\begin{tabular}{|l|c|c|}
\hline Variables & $\begin{array}{c}\text { Net Income }(\mathbf{Y 1})(\mathbf{r}- \\
\text { value) }\end{array}$ & $\begin{array}{c}\text { Income }(\mathbf{Y} 2)(\mathbf{r}- \\
\text { value) }\end{array}$ \\
\hline Age $\left(\mathbf{X}_{\mathbf{1}}\right)$ & 0.103 & .008 \\
\hline Caste $\left(\mathbf{X}_{\mathbf{2}}\right)$ & $.348^{* *}$ & $.289^{* *}$ \\
\hline Family Type $\left(\mathbf{X}_{\mathbf{3}}\right)$ & $.402^{* *}$ & $.427^{* *}$ \\
\hline Family member $\left(\mathbf{X}_{\mathbf{4}}\right)$ & $-.228^{*}$ & $-.259^{* *}$ \\
\hline Education $\left(\mathbf{X}_{\mathbf{5}}\right)$ & $.605^{* *}$ & $.506^{* *}$ \\
\hline Occupation $\left(\mathbf{X}_{\mathbf{6}}\right)$ & $.721^{* *}$ & $.596^{* *}$ \\
\hline Operational Landholding $\left(\mathbf{X}_{\mathbf{7}}\right)$ & $.874^{* *}$ & $.774^{* *}$ \\
\hline House Type $\left(\mathbf{X}_{\mathbf{8}}\right)$ & .167 & $.268^{* *}$ \\
\hline Farm Power $\left(\mathbf{X}_{\mathbf{9}}\right)$ & $.877^{* *}$ & $.826^{* *}$ \\
\hline Material Possession $\left(\mathbf{X}_{\mathbf{1 0}}\right)$ & $.515^{* *}$ & $.509^{* *}$ \\
\hline Social Participation $\left(\mathbf{X}_{11}\right)$ & $.822^{* *}$ & $.749^{* *}$ \\
\hline Mass Media Exposure $\left(\mathbf{X}_{12}\right)$ & $.322^{* *}$ & $.374^{* *}$ \\
\hline Personal Cosmopolite $\left(\mathbf{X}_{13}\right)$ & -.080 & -.057 \\
\hline Personal Localite $\left(\mathbf{X}_{\mathbf{1 4}}\right)$ & -.050 & .022 \\
\hline Cost of Input $\left(\mathbf{X}_{15}\right)$ & $.873^{* *}$ & $.973^{* *}$ \\
\hline Scientific orientation $\left(\mathbf{X}_{\mathbf{1 6}}\right)$ & -.119 & -.048 \\
\hline Risk Orientation $\left(\mathbf{X}_{17}\right)$ & $.195^{*}$ & $.180^{*}$ \\
\hline
\end{tabular}


Table.3 Regression Co-efficient of net income of farmers with other causal variables

\begin{tabular}{|l|c|c|c|c|}
\multicolumn{1}{|c|}{ Variables } & B-Value & $\begin{array}{c}\text { Standard } \\
\text { Error }\end{array}$ & t- value & $\boldsymbol{\beta}$ Value \\
\hline Age $\left(\mathrm{X}_{1}\right)$ & 362.750 & 185.857 & 1.952 & .068 \\
\hline Caste $\left(\mathrm{X}_{2}\right)$ & -379.569 & 2496.178 & -.152 & -.005 \\
\hline Family Type $\left(\mathrm{X}_{3}\right)$ & -2092.916 & 3012.015 & -.695 & -.027 \\
\hline Family member $\left(\mathrm{X}_{4}\right)$ & 1582.032 & 3518.390 & .450 & .015 \\
\hline Education $\left(\mathrm{X}_{5}\right)$ & 2986.353 & 678.248 & $4.403^{* *}$ & .158 \\
\hline Occupation $\left(\mathrm{X}_{6}\right)$ & 1174.477 & 874.385 & 1.343 & .053 \\
\hline Operational Landholding $\left(\mathrm{X}_{7}\right)$ & 11627.930 & 2599.277 & $4.474^{* *}$ & .238 \\
\hline House Type $\left(\mathrm{X}_{8}\right)$ & -1123.382 & 2476.842 & -.454 & -0.016 \\
\hline Farm Power $\left(\mathrm{X}_{9}\right)$ & 12637.217 & 2395.563 & $5.275^{* *}$ & 0.273 \\
\hline Material Possession $\left(\mathrm{X}_{10}\right)$ & 278.163 & 713.071 & .390 & 0.013 \\
\hline Social Participation $\left(\mathrm{X}_{11}\right)$ & 8675.535 & 2190.789 & $3.960^{* *}$ & 0.179 \\
\hline Mass Media Exposure $\left(\mathrm{X}_{12}\right)$ & 320.764 & 715.900 & .448 & 0.014 \\
\hline Personal Cosmopolite $\left(\mathrm{X}_{13}\right)$ & -1154.246 & 811.551 & -1.422 & -0.046 \\
\hline Personal Localite $\left(\mathrm{X}_{14}\right)$ & 1356.806 & 702.661 & 1.931 & 0.059 \\
\hline Cost of Input $\left(\mathrm{X}_{15}\right)$ & 0.348 & .094 & $3.709 * *$ & 0.237 \\
\hline Scientific orientation $\left(\mathrm{X}_{16}\right)$ & -4.752 & 731.307 & -.006 & 0.000 \\
\hline Risk Orientation $\left(\mathrm{X}_{17}\right)$ & -32.387 & 390.728 & -.083 & -0.002 \\
\hline
\end{tabular}

$\mathrm{R}^{2}=0.934, \mathrm{~F}=85.392 * * ; * *$ Regression is significant at $1 \%$ and * regression is significant $5 \%$ level of significance.

Table.4 Regression co-efficient of Income (Y2) of the farmers

\begin{tabular}{|l|c|c|c|c|}
\hline \multicolumn{1}{|c|}{ Variables } & B-Value & Standard Error & t Stat & Beta Value \\
\hline Age $\left(\mathrm{X}_{1}\right)$ & -148.49 & 239.15 & -.621 & -.017 \\
\hline Caste $\left(\mathrm{X}_{2}\right)$ & 2307.44 & 3211.95 & .718 & .018 \\
\hline Family Type $\left(\mathrm{X}_{3}\right)$ & -2009.29 & 3875.70 & -.518 & -.016 \\
\hline Family member $\left(\mathrm{X}_{4}\right)$ & 4480.06 & 4527.27 & .990 & .026 \\
\hline Education $\left(\mathrm{X}_{5}\right)$ & -46.28 & 872.73 & -.053 & -.001 \\
\hline Occupation $\left(\mathrm{X}_{6}\right)$ & -1319.61 & 1125.11 & -1.173 & -.036 \\
\hline Operational Landholding $\left(\mathrm{X}_{7}\right)$ & 4508.91 & 3344.61 & 1.348 & .056 \\
\hline House Type $\left(\mathrm{X}_{8}\right)$ & 1734.52 & 3187.07 & .544 & .015 \\
\hline Farm Power $\left(\mathrm{X}_{9}\right)$ & 6254.13 & 3082.48 & 2.029 & .082 \\
\hline Material Possession $\left(\mathrm{X}_{10}\right)$ & -2326.66 & 917.54 & -2.536 & -.064 \\
\hline Social Participation $\left(\mathrm{X}_{11}\right)$ & 5114.40 & 2818.99 & 1.814 & .064 \\
\hline Mass Media Exposure $\left(\mathrm{X}_{12}\right)$ & -960.23 & 921.18 & -1.042 & -.026 \\
\hline Personal Cosmopolite $\left(\mathrm{X}_{13}\right)$ & -960.23 & 1044.26 & -.395 & -.010 \\
\hline Personal Localite $\left(\mathrm{X}_{14}\right)$ & 386.93 & 904.15 & .428 & .010 \\
\hline Cost of Input $\left(\mathrm{X}_{15}\right)$ & 2.18 & 0.121 & $18.021 * *$ & .898 \\
\hline Scientific orientation $\left(\mathrm{X}_{16}\right)$ & -200.92 & 941.01 & -.214 & -.006 \\
\hline Risk Orientation $\left(\mathrm{X}_{17}\right)$ & -619.41 & 502.77 & -1.232 & -.028 \\
\hline R & & & \\
\hline
\end{tabular}

$\mathrm{R}^{2}=0.960, \mathrm{~F}=143.880 * * ; *$ Regression is significant at $1 \%$ and * regression is significant $5 \%$ level of significance. 
Table.5 Constraints perceived by the famers

\begin{tabular}{|l|c|c|c|}
\hline \multicolumn{1}{|c|}{ Paddy-cum-fish cultivated farmers } & Frequency & Percentage & Rank \\
\hline ECONOMIC CONSTRAINTS & & & \\
\hline High cost of inputs & 80 & 66.69 & II \\
\hline Lack of timely availability of fund for arranging inputs & 75 & 62.50 & III \\
\hline Non-availability of insurance when crop fails & 60 & 51.67 & I \\
\hline Lack of Market Intelligence & & 50.00 & IV \\
\hline TECHNICAL CONSTRAINTS & 45 & 41.67 & I \\
\hline Lack of knowledge of Paddy-cum-fish practices & 30 & 25.00 & II \\
\hline Lack of on-availability fish feed & 25 & 20.83 & III \\
\hline Problem of diseases in the Paddy-cum-fish cultivation & & & \\
\hline Lack of fertilizer & 55 & 45.83 & III \\
\hline COMMUNICATION CONSTRAINTS & 67 & 55.83 & I \\
\hline Irregular visit of extension worker/scientist and VLWs & 40 & 33.33 & IV \\
\hline Inadequate demonstration of new technologies & 63 & 52.50 & II \\
\hline Lack of mass-media contact & & \\
\hline Insufficient & & & \\
\hline
\end{tabular}

The $\mathrm{R}^{2}$ value is found 0.934 , which is all casual variables put together, the amount of variation in the consequent variable has been the tune of $93.40 \%$ and its F-value is 85.392 which is significant in both $5 \%$ and $1 \%$ level of significance at 119 degrees of freedom.

Table 4 shows the multiple regression analysis of Income. From table 4 it is clear that farm power, material possession, cost of input have the substantial effect on net income of paddy-cum-fish cultivation farmers. A unit change in the cost of input has contributed to the proportion of 0.898 units change to the income of the paddy-cum-fish cultivation farmers. Similarly, a unit change in farm power, material possession, cost of input will yield the change in the level of income of the farmers by $0.082,-0.064$ and 0.898 respectively.

The $\mathrm{R}^{2}$ value is found 0.960 , which is all causal variables put together, the amount of variation in the consequent variable has been to the tune of 96 percent and it's F-value 143.88 which is significant in both $5 \%$ and $1 \%$ level of significance at 119 degrees of freedom.
From table 5 for constraints perceived, the result was studied from the frequency and percentage of each item was summaries and the constraints have been ranked according to the percentage. Economical constraints reveal that Non-availability of insurance when the crop fails has the highest frequency and lack of market intelligence as the lowest frequency of constraining from the respondents respectively as there is no support from the government and private sector for the cultivation policy. Technical constraints reveal that lack of knowledge of Paddy-cumfish practices has the highest frequency and lack of fertilizer as the lowest frequency of constraining from the respondents respectively as the farmers are still using a primitive or traditional method of cultivation. Lastly, for communication constraints reveal that inadequate demonstration of new technologies has the highest frequency and lack of mass-media contact as the lowest frequency of constraining from the respondents respectively as the farmers face lack of government and private sector support for training and impartment of new knowledge to the farmers. With the increase in demand for fish consumption, there is a 
need to increase production of fish in Manipur. This gives scope for the improvement of fish farming practices in Manipur so as to meet the growing demand of the population and to improve rural economy of the state. Integration of rice cultivation with fish farming enables optimum utilization of available local resources, by turning the practice into a low input self-supporting system if the appropriate location-specific refinement of packages of practices is achieved. Paddy-cum-fish cultivation is beneficial for the farmers of Manipur as integrated farming reduces the risk of separate cultivation of paddy and fish monoculture and generates more net income and income for the farmers with minimum input. Therefore both public and private organizations should put a thrust on identifying the innovative method of traditional fish farming practices and develop need-based and location specific and low-cost technology that will improve fish productivity and deliver sustainable development of the farming community in Manipur.

\section{Acknowledgment}

Above all, I would like to thank the coauthors for their kind support and valuable guidance, while conducting the research and regarding the revision of this paper

\section{References}

Ahmad N, Zander K K, Garnett S T. 2011. Socioeconomic aspects of rice-fish farming in Bangladesh: Opportunities, challenges and production efficiency. Austr J Agric Res Econ, 55: 199-219.

Ahmed N, Garnett S T. 2011. Integrated rice-fish farming in Bangladesh: Meeting the challenges of food security. Food Sec, 3(1): 81-92

Ahmed N, Luong-Van J. 2009. Can rice-fish farming provide food security in Bangladesh? Aqua Asia Mag, 14(1): 18-23.
Das D R, Quddus M A, Khan A H, Nur-e-Elahi M. 2002. Farmer's participatory productivity evaluation of integrated rice and fish systems in transplanted Aman rice. Pak J Agron, 1(2/3): 105-106.

Edwards P. 2002. Aquaculture for poverty alleviation and food security. Aquacul Asia, 7(2): 53- 56.

Frei M, Becker K. 2005. Integrated rice-fish culture: Coupled production saves resources. Nat Res Forum, 29: 135-143.

International Development Research Centre (IDRC). 1998. Rice-fish culture. Available online: http://www.yale.edu/macmillan/ pier/resources/lessons/apdxii.pdf

Lu J B, Li X. 2006. Review of rice-fish-farming systems in China: One of the Globally Important Ingenious Agricultural Heritage Systems (GIAHS). Aquaculture, 260: 106-113.

Noorhosseini S A, Radjabi R. 2010. Decline application of insecticide and herbicides in integrated rice-fish farming: The case study in north of Iran. Am Eur $J$ Agric Environ Sci, 8(3): 334-338.

Noorhosseini S A. 2010. Fish Farming in Rice Fields toward Sustainable Agriculture: The Case Study in Guilan Province. The First National Conference on Sustainable and Cleaner Product, Esfahan of Iran, Nov 10-11, 2010.

Okoye F C. 2004. Integrated rice fish farming in Nigeria: Its feasibility and economic viability. In: 18th Annual Conference of the Fisheries Society of Nigeria (FISON), 8-12 December, 2003, Owerri, Nigeria.

Pullin R. S. V. 1989. Third-world aquaculture and the environment. Naga, ICLARM 12: 10-13.

Rabbani M G, Islam M S, Hossain M I, Hossain T M B, Begum M E A. 2004. An economic study on alternate rice-fish culture in selected areas of Mymensingh District in Bangladesh. Pak J Biol Sci, 7(5): 685-688.

Rahman M A, Heidhues F, Becker K. 2005. Socioeconomic impact of rice-cum-fish culture in Bangladesh. In: Proceedings of the Global Food \& Product Chain-Dynamics, Innovations, Conflicts, Strategies. Deutscher Tropentag, October 11-13, 2005, Hohenheim.

Saikia S K, Das D N. 2008. Rice-fish culture and its potential in rural development: A lesson from Apatani farmers, Arunachal Pradesh, India. J Agric Rural Dev, 6: 125-131.

Tasnoova S, Iqbal K M, Iwamoto I, Haque M M. 2008. Economic performance of fish based farming systems in Bangladesh. J fish Aquat Sci, 3(3): 206-212.

\section{How to cite this article:}

Haobijam, J.W., Marak R. Balkho and Mandal, T.K. 2018. Paddy-Cum-Fish Cultivation and the Challenges Face by the Farmers of Manipur. Int.J.Curr.Microbiol.App.Sci. 7(02): 9981004. doi: https://doi.org/10.20546/ijcmas.2018.702.123 